\title{
Analisis Neraca Air Permukaan DAS Ciliman
}

\author{
Isvan Taufik1, Muhammad Yanuar J. Purwanto², Bambang Pramudya², Satyanto K. \\ Saptomo ${ }^{2}$
}

1Program Doktor Sekolah Pascasarjana Institut Pertanian Bogor, e-mail: isvantaufik@gmail.com

${ }^{2}$ Institut Pertanian Bogor, Baranangsiang Bogor Jawa Barat

\begin{abstract}
ABSTRAK
DAS Ciliman merupakan salah satu DAS terbesar kedua di Propinsi Banten dan menjadi bagian dari Wilayah Sungai CilimanCibungur, perkembangannya semakin pesat sejak adanya rencana pembangunan Bandara Panimbang, Kawasan Ekonomi Khusus Tanjung Lesung, dan Pembangunan Jalan Tol Serang-Panimbang. Disamping itu, sekitar DAS Ciliman terhampar Daerah Irigasi Ciliman seluas 5.423 Ha yang merupakan lumbung padi nasional. Kondisi tersebut menyebabkan DAS Ciliman sangat penting dalam menunjang ketahanan pangan, ketahanan air, dan ketahanan ekonomi di Propinsi Banten sehingga perlu dilakukan analisis neraca air pada DAS Ciliman. Neraca air merupakan estimasi ketersediaan dan kebutuhan air pada suatu wilayah DAS. Neraca air tersebut menjadi sangat penting mengingat kebutuhan manusia akan sumberdaya air menjadi kebutuhan utama. Tujuan penelitian ini, meliputi; (1) Menganalisis sebaran pengaruh stasiun pengamatan curah hujan pada masing-masing Sub DAS Ciliman, (2) Menganalisis debit andalan pada masing-masing Sub DAS Ciliman, dan (3) Menganalisis potensi ketersediaan air baku pada DAS Ciliman. Metode analisis data yang digunakan meliputi; analisis curah hujan wilayah, analisis ketersediaan air (analisis evapotranspirasi, analisis model Mock), dan analisis kebutuhan air. Hasil analisa ketersediaan air di Bendung Ciliman sebesar 103,94 m³/detik, sedangkan kebutuhan airnya sebesar 103,11 m³/detik. Hal ini berarti terdapat surplus sebesar $0,83 \mathrm{~m}^{3} /$ detik. Berdasarkan analisa perhitungan neraca air seluruh DAS Ciliman terdapat surplus sebesar $99 \mathrm{~m}^{3} /$ detik.
\end{abstract}

Kata kunci: Neraca air, ketersediaan air, kebutuhan air, curah hujan, DAS Ciliman

\section{ABSTRACT}

Ciliman Watershed is one of the second largest watersheds in Banten Province, as a part of the Ciliman-Cibungur River Region, has been developed since there are several planned such as Panimbang Airport, Tanjung Lesung Special Economic Zone, and Construction of Serang-Panimbang Toll Road. In addition, around the Ciliman watershed stretches into the Ciliman Irrigation Area covering an area of 5,423 hectares as the national rice barn. These conditions cause the Ciliman watershed to be very important in supporting food security, water security, and economic security in Banten Province, so it is necessary to do a water balance analysis in the Ciliman watershed. Water balance is an estimate of the availability and needs of water in a watershed area. The water balance is very important considering the human need for water resources is a major requirement. The purpose of this study includes; (1) Analyzing the distribution of the influence of rainfall observation stations in each of the Ciliman sub-watersheds, (2) Analyzing the mainstay discharge in each Ciliman sub-watershed, and (3) Analyzing the potential availability of raw water in the Ciliman watershed. Data analysis methods used include; regional rainfall analysis, analysis of water availability (evapotranspiration analysis, Mock model analysis), and analysis of water requirements. The results of the analysis of water availability in Bendung Ciliman are $103.94 \mathrm{~m}^{3} / \mathrm{second}$, while the water demand is $103.11 \mathrm{~m}^{3} /$ second. This means that there is a surplus of $0.83 \mathrm{~m}^{3} /$ second. Based on the analysis of the calculation of the water balance throughout the Ciliman watershed there is a surplus of $99 \mathrm{~m}^{3} / \mathrm{second}$.

Keywords: Water balance, water availability, water needs, rainfall, Ciliman watershed

Citation: Taufik, I., Purwanto, M. Y. J., Pramudya, B., dan Saptomo, S. K. (2019). Analisis Neraca Air Permukaan DAS Ciliman. Jurnal Ilmu Lingkungan, 17(3),452-464, doi:10.14710/jil.17.3.452-464

\section{Latar Belakang}

Kebutuhan manusia akan sumberdaya air menjadi sangat nyata bila dikaitkan dengan empat hal, yaitu pertambahan penduduk, pertumbuhan pangan, peningkatan industrialisasi dan perlindungan ekosistem terhadap teknologi. DAS Ciliman yang terletak di Propinsi Banten yang menjadi salah satu DAS terbesar kedua dan menjadi bagian dari Wilayah Sungai Ciliman-Cibungur, memiliki potensi Sumberdaya Air yang sangat strategis yang salah satunya dimanfaatkan untuk mengairi Daerah Irigasi Ciliman seluas 5.423 Ha yang merupakan salah satu lahan sawah beririgasi teknis yang terbesar di Kabupaten Pandeglang dan penyumbang lumbung padi nasional. Selain itu, pada DAS Ciliman juga terdapat daerah irigasi kewenangan Provinsi Banten, yaitu DI.Cimanyangray sebagai daerah potensial kawasan strategis pangan, serta daerah irigasi dengan luas $<1.000$ hektar yang merupakan kewenangan Kabupaten Pandeglang dan Kabupaten Lebak. Jika dilihat dari neraca airnya, kebutuhan air irigasi merupakan kebutuhan air paling tinggi di WS Ciliman-Cibungur diikuti oleh air domestik kemudian industri dan peternakan (Dinas Sumber Daya Air dan Pemukiman Provinsi Banten 2013). Hal tersebut secara tidak langsung 
mengisyaratkan bahwa dengan adanya daerah irigasi yang merupakan hamparan sawah beririgasi teknis sebagai satu kawasan strategis pangan berbasis komoditas unggulan pangan pada DAS Ciliman, maka kebutuhan air irigasinya harus dijamin (disediakan) dan dikelola secara layak oleh pemerintah/ pemerintah provinsi/ pemerintah kabupaten sesuai dengan kewenangannya.

Disisi lain, penyediaan air irigasi untuk daerah potensial kawasan strategis pangan tersebut mendapatkan tantangan dengan diterbitkannya Peraturan Presiden Republik Indonesia Nomor 3 Tahun 2016 tentang percepatan pelaksanaan proyek strategis nasional, antara lain 1)Kawasan Ekonomi Khusus (KEK) Tanjung Lesung seluas 1.500 hektar membutuhkan penyediaan air sebesar 400 liter/detik, 2)Pembangunan Bandara Banten Selatan dan Jalan Tol Serang-Panimbang sepanjang 83,6 kilometer yang salah satu trasenya memotong sungai Ciliman, akan memicu pertumbuhan pusat-pusat kegiatan baru dan lonjakan pertumbuhan penduduk dan berimplikasi pada berubahnya tata guna lahan disekitar DAS Ciliman tersebut dan kebutuhan air baku semakin bertambah.

Besar kecilnya sumber daya air pada suatu DAS sangat tergantung dari jumlah curah hujan yang ada pada DAS. Untuk mengetahui potensi sumber daya air pada suatu wilayah perlu dilakukan analisis ketersediaan debit untuk mendapatkan data time series yang andal yang cukup panjang pada setiap simpul aliran (pada sub-DAS yang terletak dibagian hulu). Permasalahannya terletak pada data debit yang sangat terbatas jumlah ketersediaannya, sehingga perlu dilakukan analisis debit andalan atas dasar data-data hujan dan iklim. Beberapa penelitian telah dilakukan pada DAS Ciliman, diantaranya yaitu Dinas Sumber Daya Air dan Permukiman (2014) melakukan kajian melalui paket pekerjaan DED Penyediaan Air bAku Kawasan Tanjung Lesung, Dinas Sumber Daya Air dan Permukiman (2015) Studi Komprehensif Pengendalian Daya Rusak Air pada DAS Ciliman, Dinas Sumber Daya Air dan Permukiman (2016) Penyusunan Perencanaan dan Evaluasi Alokasi Air Pada DAS Ciliman, Dirjen Cipta Karya Kementerian PUPR (2016) Perencanaan Pengembangan SPAM Mendukung Kawasan Strategis Pariwisata Nasional Wilayah Barat, Dinas Pekerjaan Umum dan Penataan Ruang (2017-2018) Pra FS dan FS Pembangunan Multipurpose DAM pada DAS Ciliman, Mubarok (2018) melakukan penelitian tentang Perencanaan Bendungan Ciliman di Kabupaten Lebak, Banten. Sedangkan penelitian lain mengenai ketersediaan air di lokasi lain, antara lain : Evaluasi Ketersediaan Air DAS Deli terhadap Kebutuhan Air (Sitompul dan Efrida, 2018), Analisa Ketersediaan dan Kebutuhan Air pada DAS Sampean (Sari dkk, 2011), Analisa Ketersediaan dan Kebutuhan Air pada DAS Percut untuk Memenuhi Kebutuhan Air Bersih di Kabupaten Deli Serdang (Sukmanda dan Terunajaya, 2016). Tujuan penelitian ini, meliputi: (1) Menganalisis sebaran pengaruh stasiun pengamatan curah hujan pada masing-masing Sub DAS Ciliman, (2) Menganalisis debit andalan pada masing-masing Sub DAS Ciliman, dan (3) Menganalisis potensi ketersediaan dan kebutuhan air baku pada DAS Ciliman.

\section{Metodologi}

\subsection{Jenis dan sumber data}

Jenis data yang digunakan dalam kajian ini adalah data sekunder yang meliputi: (1) data curah hujan bulanan dari 4 stasiun pengamatan curah hujan Tahun 1998-2015, yaitu stasiun pengamatan curah hujan Bendung Ciliman, Bojong Manik, Gunung Kencana, dan stasiun pengamatan curah hujan KP3, (2) data klimatologi Stasiun BMKG Taktakan Serang Tahun 1998-2015, (3) Peta DAS Ciliman dan (4) Data jumlah penduduk.

\subsection{Kerangka Penelitian}

Kerangka penelitian analisis ketersediaan air terhadap kebutuhan air di DAS Ciliman dalam penelitian ini diperlihatkan pada Gambar 2.

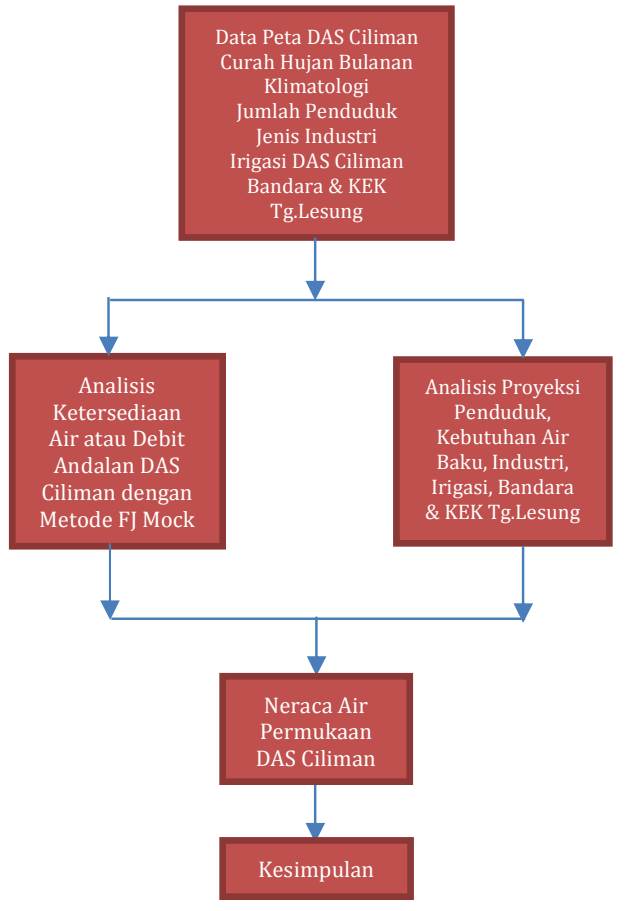

Gambar 1 Kerangka Tahapan Penelitian

\subsection{Metode pengumpulan data}

Metode pengumpulan data dilakukan dengan metode studi pustaka (desk study) yang dilakukan pada beberapa instansi terkait, diantaranya; Stasiun BMKG Taktakan Serang, Dinas PUPR Provinsi Banten, BBWS Cidanau Ciujung Cidurian Kementerian PUPR, serta BPS Provinsi Banten.

\subsection{Metode analisis data}

Metode analisis data yang digunakan meliputi; analisis curah hujan wilayah, analisis ketersediaan air (analisis evapotranspirasi, analisis Mock), dan 
analisis kebutuhan air. Analisis curah hujan wilayah dengan metode Thiesen dilakukan untuk mengetahui sebaran pengaruh tangkapan hujan terhadap hujan disekitarnya. Rata-rata terbobot (weighted average), masing-masing stasiun hujan ditentukan luas daerah pengaruhnya berdasarkan poligon yang dibentuk (menggambarkan garis-garis sumbu pada garis-garis penghubung diantara stasiun hujan yang berdekatan).

Analisis ketersediaan dilakukan dengan pendekatan analisis evapotranspirasi dan analisis Mock. Penentuan nilai evapotranspirasi pada penelitian ini dilakukan dengan menggunakan metode Penman. Rumus yang menjelaskan evapotranspirasi acuan secara teliti adalah rumus Penman-Monteith, yang pada tahun 1990 oleh FAO dimodifikasi dan dikembangkan menjadi rumus FAO Penman-Monteith (Anonim, 1999) yang diuraikan sebagai berikut:

$$
E T_{0}=\frac{0.408 \Delta(R n-G)+\gamma \frac{900}{T+273} u_{2}\left(e_{s}-e_{a}\right)}{\Delta+\gamma\left(1+0.34 u_{2}\right)}
$$

Keterangan:

ETo=Evapotranspirasi acuan $(\mathrm{mm} /$ hari $)$

$R n=$ Radiasi netto pada permukaan tanaman

(MJ/m²/hari)

$G=$ Kerapatan panas terus-menerus pada tanah

(MJ/m²/hari)
$T=$ Temperatur harian rata-rata pada ketinggian $2 \mathrm{~m}$

$\left({ }^{\circ} \mathrm{C}\right)$

u2=Kecepatan angin pada ketinggian $2 \mathrm{~m}(\mathrm{~m} / \mathrm{s})$

es=Tekanan uap jenuh $(\mathrm{kPa})$

ea=Tekanan uap aktual $(\mathrm{kPa})$

$D=$ Kurva kemiringan tekanan uap $\left(\mathrm{kPa} /{ }^{\circ} \mathrm{C}\right)$

$g=$ Konstanta psychrometric $\left(\mathrm{kPa} /{ }^{\circ} \mathrm{C}\right)$

Sedangkan analisis Mock merupakan analisis keseimbangan air untuk menghitung harga debit bulanan berdasarkan tranformasi data curah hujan bulanan, evapotranspirasi, kelembaban tanah dan tampungan air tanah. Metode empiris tersebut digunakan apabila terdapat catatan debit sungai yang hilang (Mock, 1973). Prinsip metode Mock menyatakan bahwa hujan yang jatuh pada daerah tangkapan air, sebagian akan hilang akibat evapotranspirasi, sebagian akan langsung menjadi direct runoff dan sebagian lagi akan masuk ke dalam tanah atau terjadi infiltrasi. Infiltrasi ini mula-mula akan menjenuhkan permukaan tanah, kemudian terjadi perkolasi ke air tanah dan akan keluar sebagai base flow. Hal ini terdapat keseimbangan antara air hujan yang jatuh dengan evapotranspirasi, direct runoff dan infiltrasi, dimana infiltrasi ini kemudian berupa soil moisture dan ground water discharge. Aliran dalam sungai adalah jumlah aliran yang langsung di permukaan tanah dan base flow.

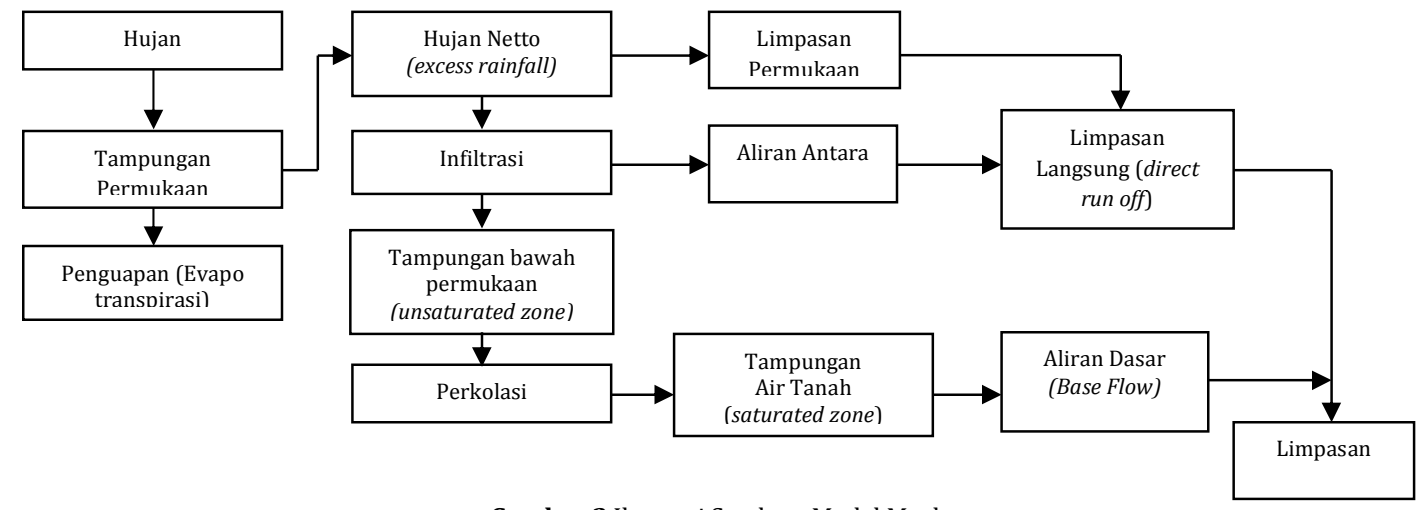

Gambar 2 Ilustrasi Struktur Model Mock

Analisis kebutuhan air meliputi; analisis kebutuhan untuk irigasi, dan analisis kebutuhan air domestik, munisipal dan industri (DMI), kebutuhan air untuk kawasan khusus ekonomi Tanjung Lesung. Kebutuhan air irigasi di sawah diestimasi untuk pola tanam padi-padi-palawija, sebagai berikut:

- Kebutuhan bersih air di sawah untuk padi (NFR): $\mathrm{NFR}=\mathrm{ET} \mathrm{c}+\mathrm{P}-\mathrm{Re}+\mathrm{WLR}$

- Kebutuhan air irigasi untuk padi (WRD): $\mathrm{IR}=\mathrm{NFR} / \mathrm{e}$

- Kebutuhan air irigasi untuk palawija (WRP): $\mathrm{IR}=(\mathrm{ET} \mathrm{c}-\mathrm{Re}) / \mathrm{e}$

Dimana:

ET $c=$ Penggunaan konsumtif $(\mathrm{mm} /$ hari $)=$ ET o $\times C$ $C=$ Koefisien tanaman rata-rata ET o=Evapotranspirasi potensial ( $\mathrm{mm} /$ hari)
$P=$ Kehilangan air akibat perkolasi $(\mathrm{mm} /$ hari),$P=2$ $\mathrm{mm} /$ hari

$\mathrm{Re}=$ Curah hujan efektif ( $\mathrm{mm} /$ hari)

$e=$ Efisiensi irigasi secara keseluruhan

$W L R=$ Penggantian lapisan air ( $\mathrm{mm} /$ hari), yang dilakukan 2 bulan setelah transplantasi selama jangka waktu 15 hari, setinggi $50 \mathrm{~mm}$ atau $3.3 \mathrm{~mm} /$ hari

Total kebutuhan air DMI diestimasi dengan mengalikan populasi hasil proyeksi dengan laju konsumsi air per kapita, sebagaimana ditunjukkan dalam rumus berikut:

$\mathrm{Q}_{(\text {DMI })}=365 \cdot\left(\frac{\mathrm{q}_{(\mathrm{u})}}{1000} \cdot \mathrm{P}_{(\mathrm{u})}+\frac{\mathrm{q}_{(\mathrm{r})}}{1000} \cdot \mathrm{P}_{(\mathrm{r})}\right)$

Dimana:

$Q(D M I)=$ kebutuhan air DMI $\left(\mathrm{m}^{3} /\right.$ tahun $)$ 
$q(u)=$ konsumsi air untuk daerah perkotaan (lit/kapita/hari)

$q(r)=$ konsumsi air untuk daerah pedesaan (lit/kapita/hari)

$P(u)=$ populasi perkotaan

$P(r)=$ populasi pedesaan

\section{Hasil dan Pembahasan}

\subsection{Analisis curah hujan}

Analisis curah hujan wilayah membandingkan luas pengaruh keempat stasiun pengamatan curah hujan dengan debit bulanan masing-masing stasiun pengamatan curah hujan, sehingga diperoleh hasil curah hujan wilayah untuk tiap Sub DAS pada DAS Ciliman. Data hujan yang dibutuhkan untuk perencanaan adalah data hujan harian dan hujan bulanan yang diperoleh dari stasiun hujan yang berpengaruh pada daerah tangkapan air tersebut. Data curah hujan dari 4 Pos Curah Hujan yang berpengaruh terhadap besarnya debit sungai Ciliman dan anak-anak sungainya, yaitu: yaitu: PCH Gn. Kencana, PCH Bd. Ciliman, PCH KP3, dan PCH Bojongmanik.
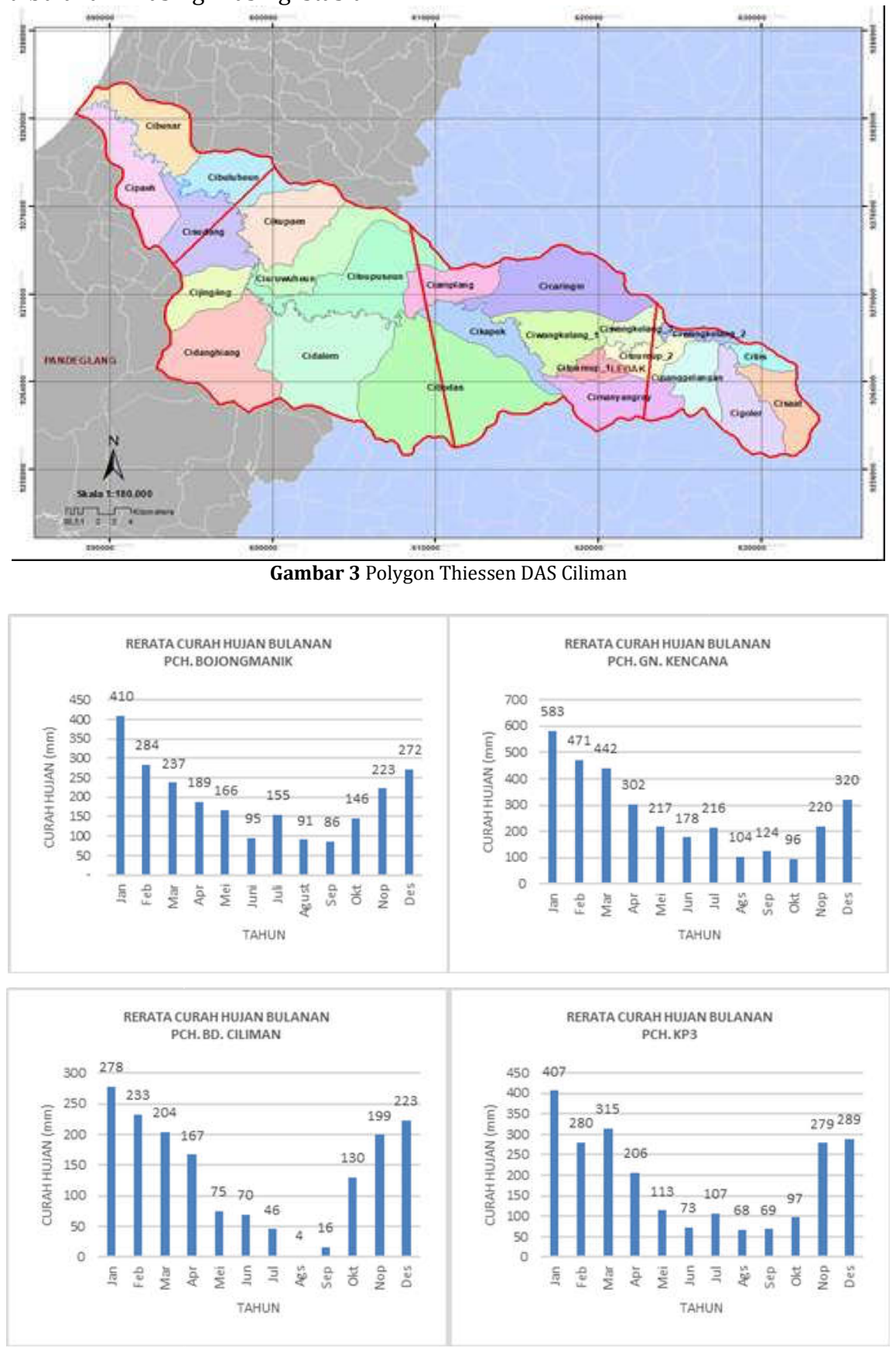

Gambar 4 Grafik Curah Hujan Bulanan 4 PCH DAS Ciliman 
Data pada gambar 4 menunjukkan curah hujan bulanan pada 4 PCH di DAS Ciliman. Grafik menunjukkan pola yang mirip dengan curah hujan tertinggi terjadi pada bulan Januari, dan curah hujan terendah terjadi pada bulan Agustus. Agar hasil analisis curah yang diperoleh cukup valid untuk menghasilkan hasil analisa hidrologi yang baik, maka pemeriksaan terhadap konsistensi perlu dilakukan.

Pengujian konsistensi data pada penelitian menggunakan Metode Double Mass Curve yaitu membandingkan data hujan kumulatif stasiun yang diuji dengan kumulatif rata-rata data stasiun hujan lainnya. Pengujian dengan metode ini akan memberikan hasil yang baik, jika dalam suatu DAS terdapat banyak stasiun hujan, karena dengan jumlah stasiun hujan yang banyak akan memberikan nilai rata-rata hujan tahunan sebagai pembanding terhadap stasiun yang di uji lebih dapat mewakili secara baik. Oleh karena itu jumlah minimal stasiun hujan untuk pengujian ini adalah 3 stasiun hujan dan jika hanya terdapat 2 stasiun hujan atau bahkan 1 stasiun hujan, maka tidak dapat dilakukan pengujian konsistensi data hujan dan oleh karenanya kita asumsikan bahwa data yang ada adalah konsisten. Berikut adalah hasil pemeriksaan konsistensi curah hujan pada 4 stasiun.
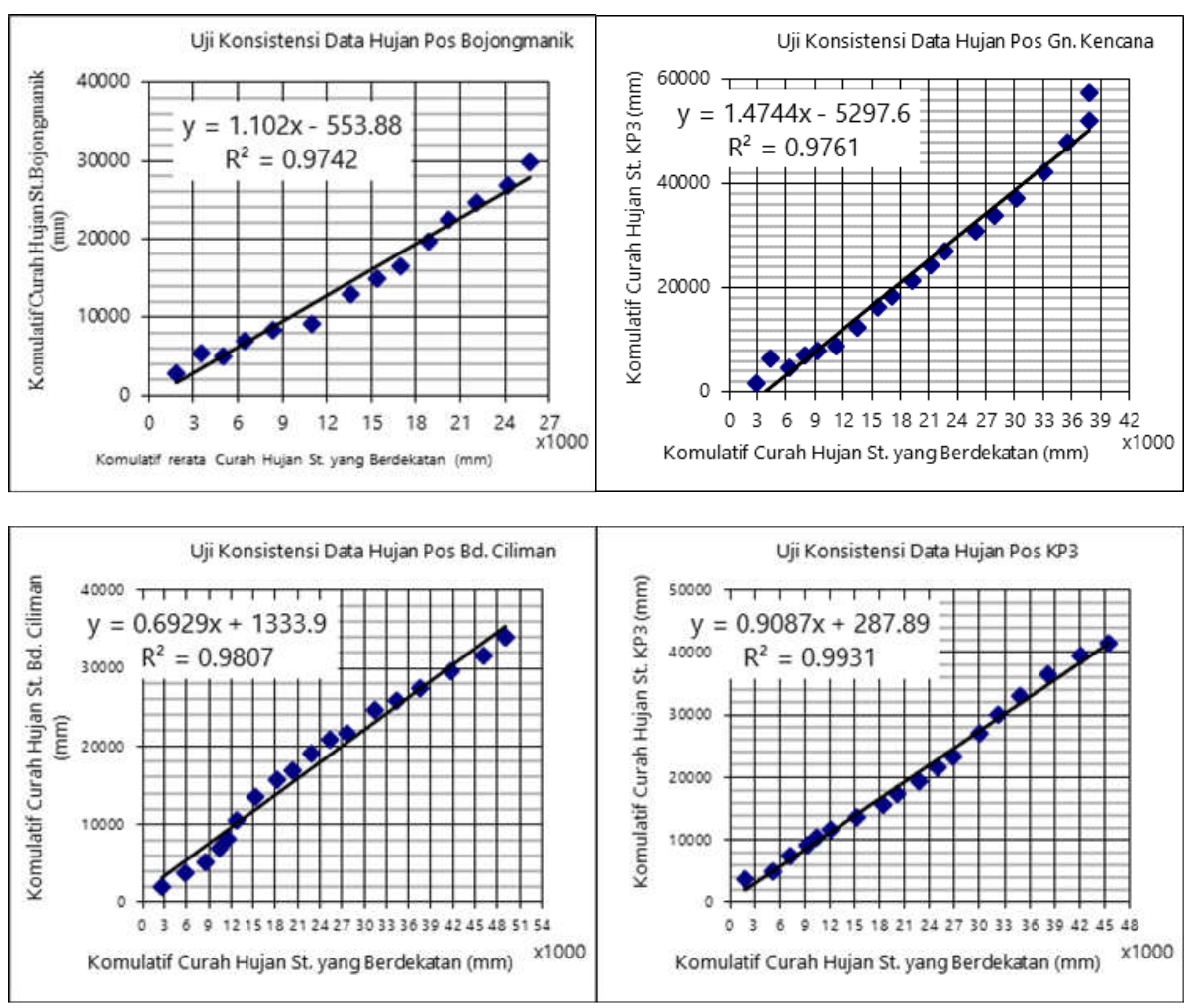

Gambar 5 Hasil Uji Konsistensi Data Hujan4 PCH di DAS Ciliman

Berdasarkan garis yang terbentuk dari grafik, data hujan pada PCH Gunung Kencana dan PCH Bendung Ciliman tergolong cukup baik dan dapat digunakan dalam penelitian ini. Grafik yang terbentuk pada mengahsilkan trend yang mendekati garis lurus dan tidak mengalami patahan-patahan atau pembelokan garis yang signifikan. Sedangkan pada grafik data hujan PCH Bojongmanik dan PCH KP3, berdasarkan trend yang terbentuk dari grafik, data hujan pada 2 PCH tersebut tergolong kurang baik. Dari hasil uji konsistensi data hujan menunjukkan bahwa data hujan dari keempat stasiun pengamatan hujan tersebut konsisten sehingga tidak diperlukan koreksi.

\subsection{Analisis ketersediaan air}

Analisis ketersediaan air terkait debit kontinyu, membutuhkan data debit dalam rentang periode yang panjang. Pembangkitan data debit dapat dilakukan dengan model hujan aliran (rainfall run off model), salah satunya adalah model Mock, yaitu salah satu contoh model hidrologi sederhana yang umum digunakan untuk menghitung besarnya debit sungai dengan mentransformasi hujan aliran mengikuti prinsip keseimbangan air (water balance) untuk memperkirakan ketersediaan air (debit) suatu sungai (Tunas dan Lesmana, 2011). Ketersediaan air dianalisis dengan perhitungan debit andalan di masing-masing DAS orde-2. DAS Ciliman dibagi menjadi beberapa sub-DAS utama. Debit andalan diestimasi dengan menggunakan metode Mock. Pada prinsipnya, Metoda Mock memperhitungkan volume air yang masuk, keluar, dan yang disimpan dalam tanah (soil storage). Volume air yang masuk adalah hujan. Air yang keluar adalah infiltrasi, perkolasi dan 
yang dominan adalah akibat evapotranspirasi. Perhitungan evapotranspirasi menggunakan metoda Penmann-Monteith. Sementara soil storage adalah volume air yang disimpan dalam pori-pori tanah, hingga kondisi tanah menjadi jenuh.

Dalam perhitungan debit tiap sub-DAS, digunakan parameter-parameter yang dihasilkan dari perhitungan kalibrasi untuk mendapatkan parameter-parameter Mock yang sesuai dengan kondisi DAS yang dikaji. Kalibrasi ini dilakukan dengan membandingkan debit hasil perhitungan metode Mock dengan debit hasil observasi, kemudian parameter diubah-ubah hingga angka perbandingannya memiliki korelasi $>80 \%$. Hasil kalibrasi menunjukan bahwa korelasi antara debit hasil perhitungan dengan debit hasil observasi memiliki korelasi sebesar 91,61\%. Berikut adalah hasil analisis evapotranspirai DAS Ciliman.

Perhitungan debit dilakukan dengan menggunakan metode Mock yang langkah perhitungannya sama seperti proses kalibrasi namun dengan luas DAS, hujan bulanan, dan evapotranspirasi yang berbeda. Berikut adalah grafik analisi neraca air DAS Ciliman.

Tabel 1. Resume Perhitungan Evapotranspirasi DAS Ciliman Tahun 1998-2015

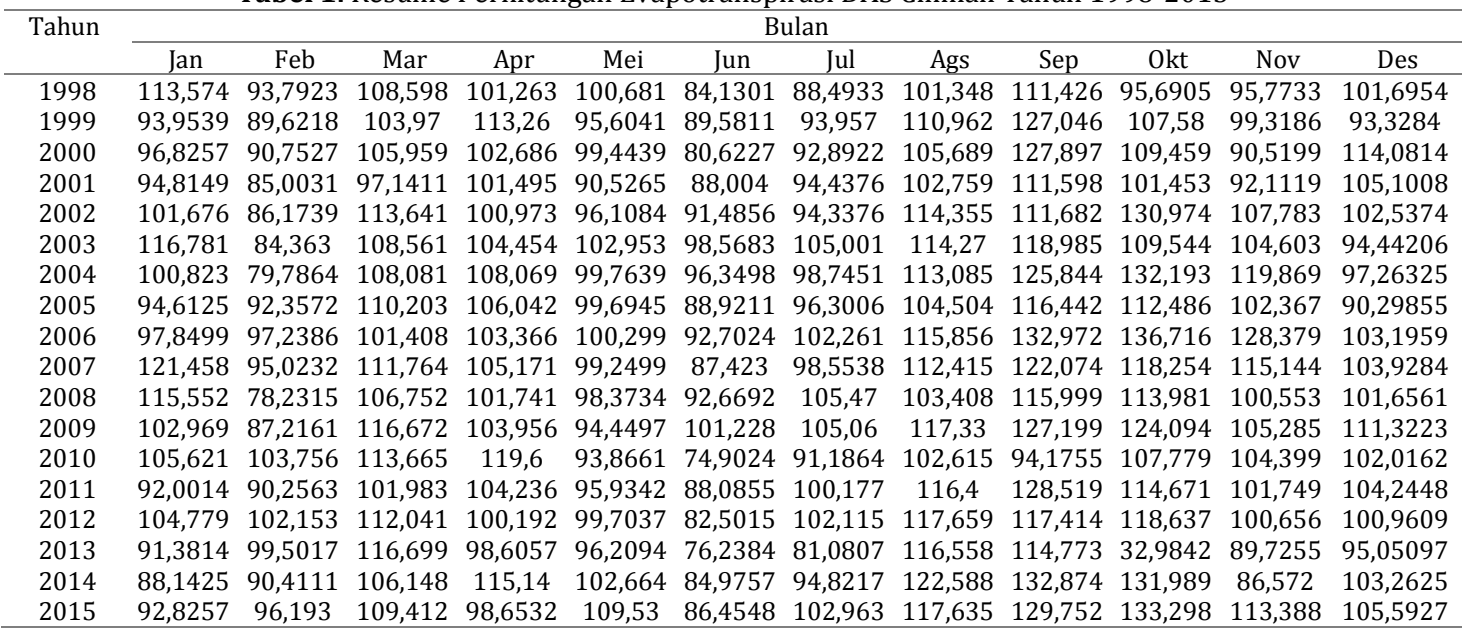

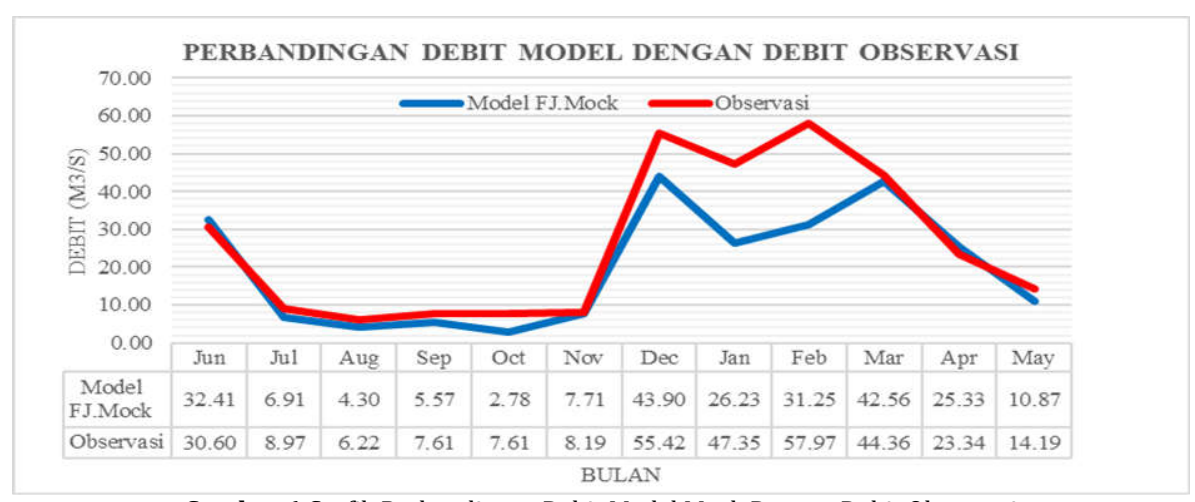

Gambar 6 Grafik Perbandingan Debit Model Mock Dengan Debit Observasi

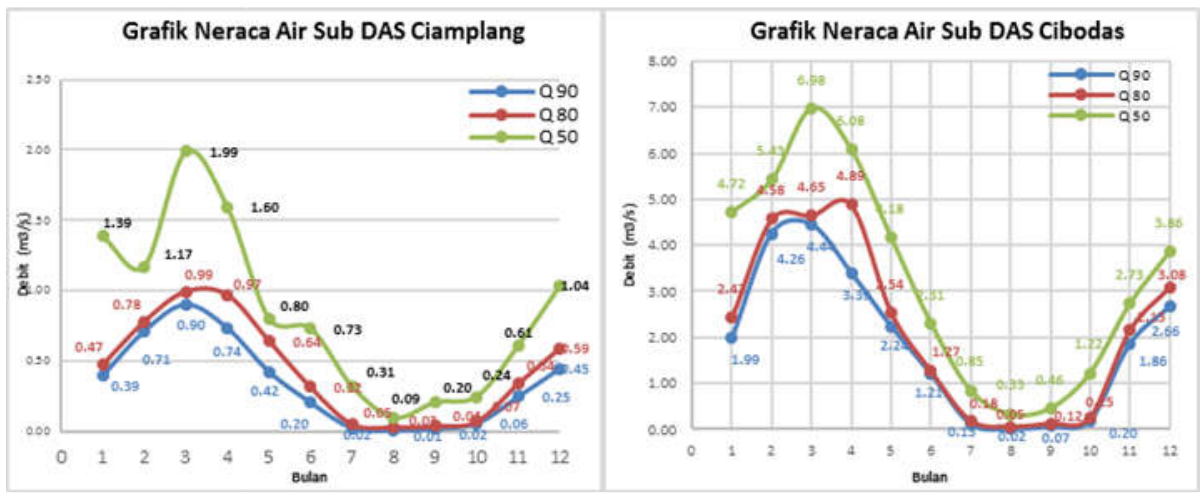



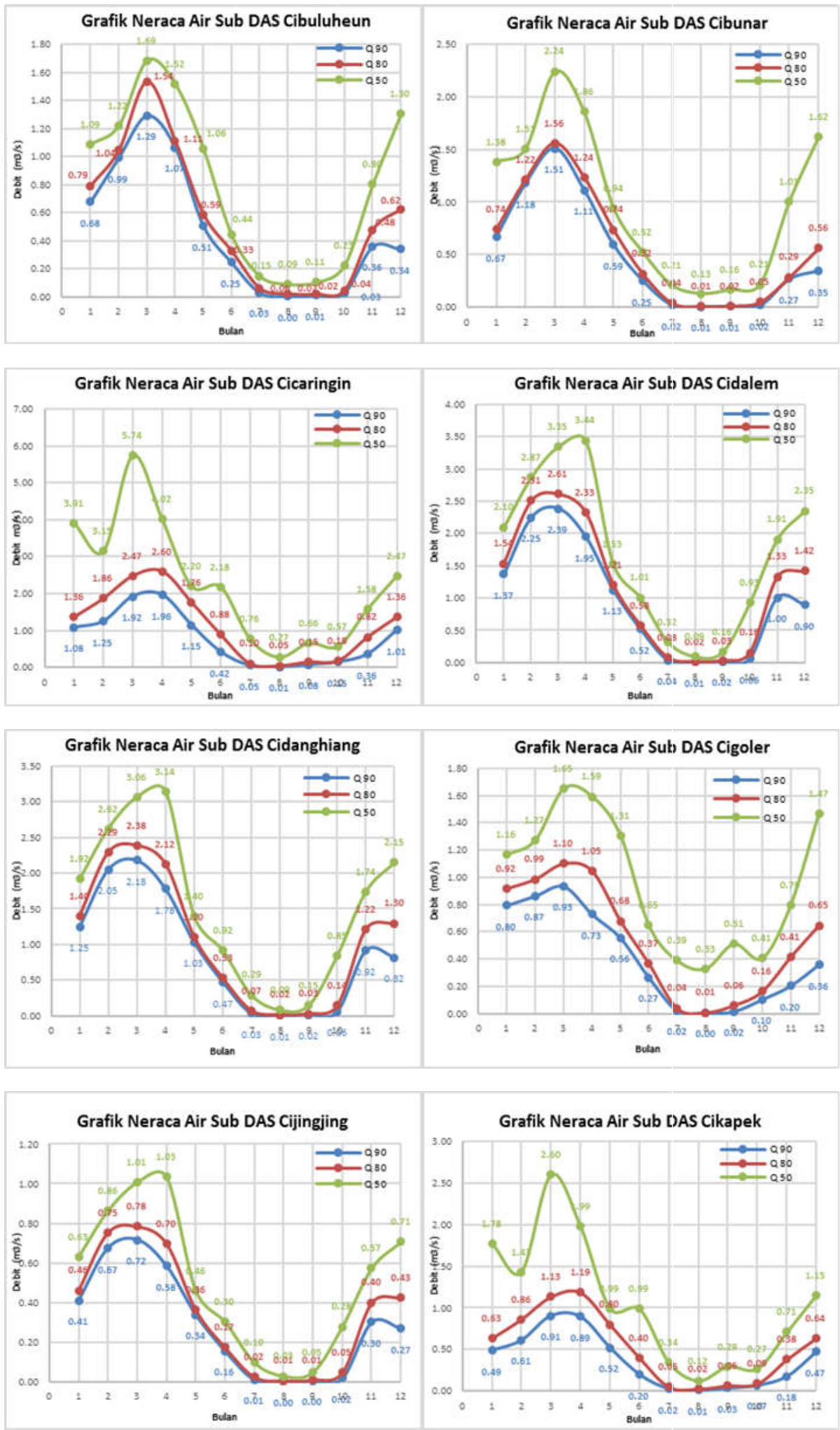

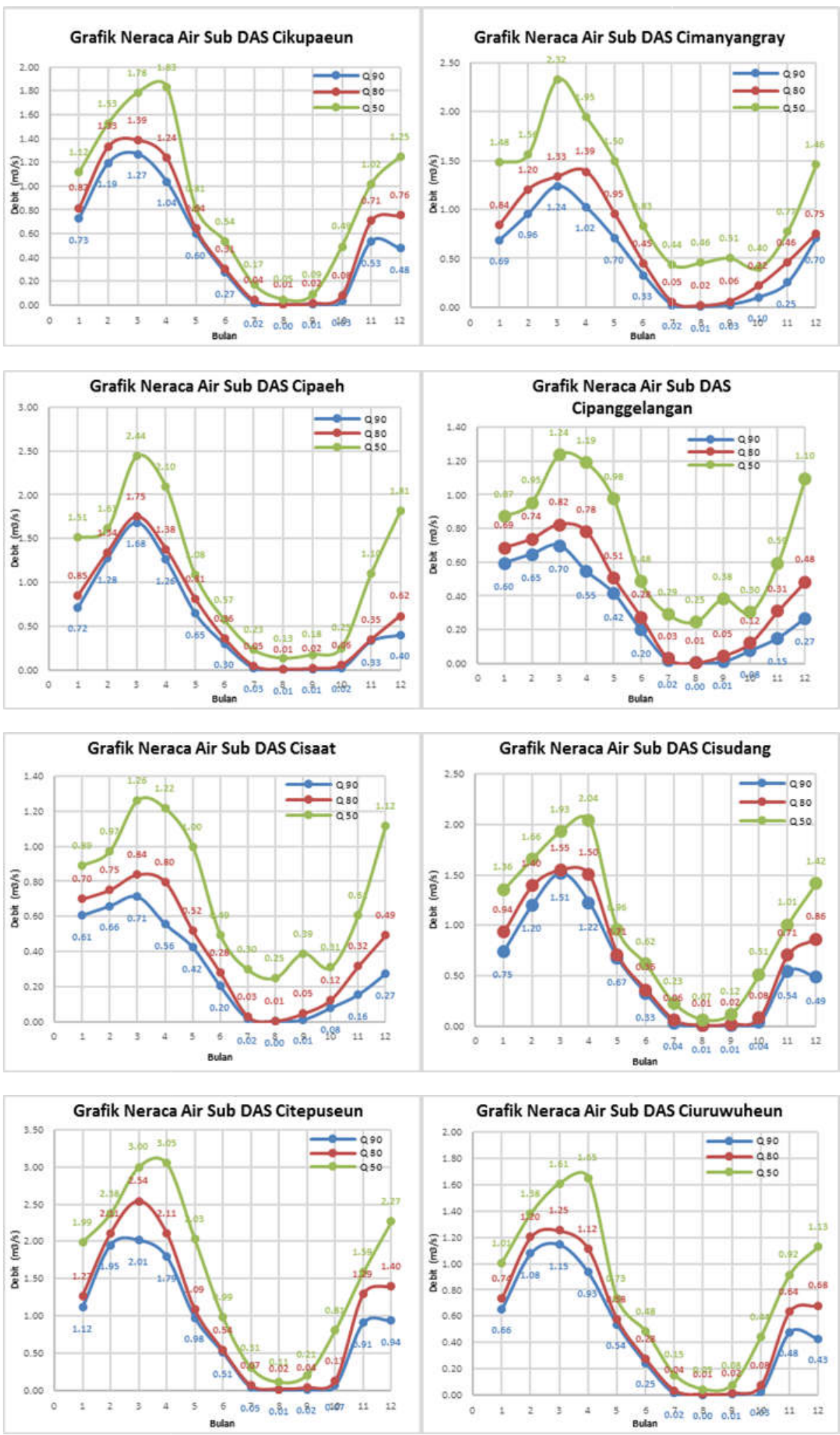

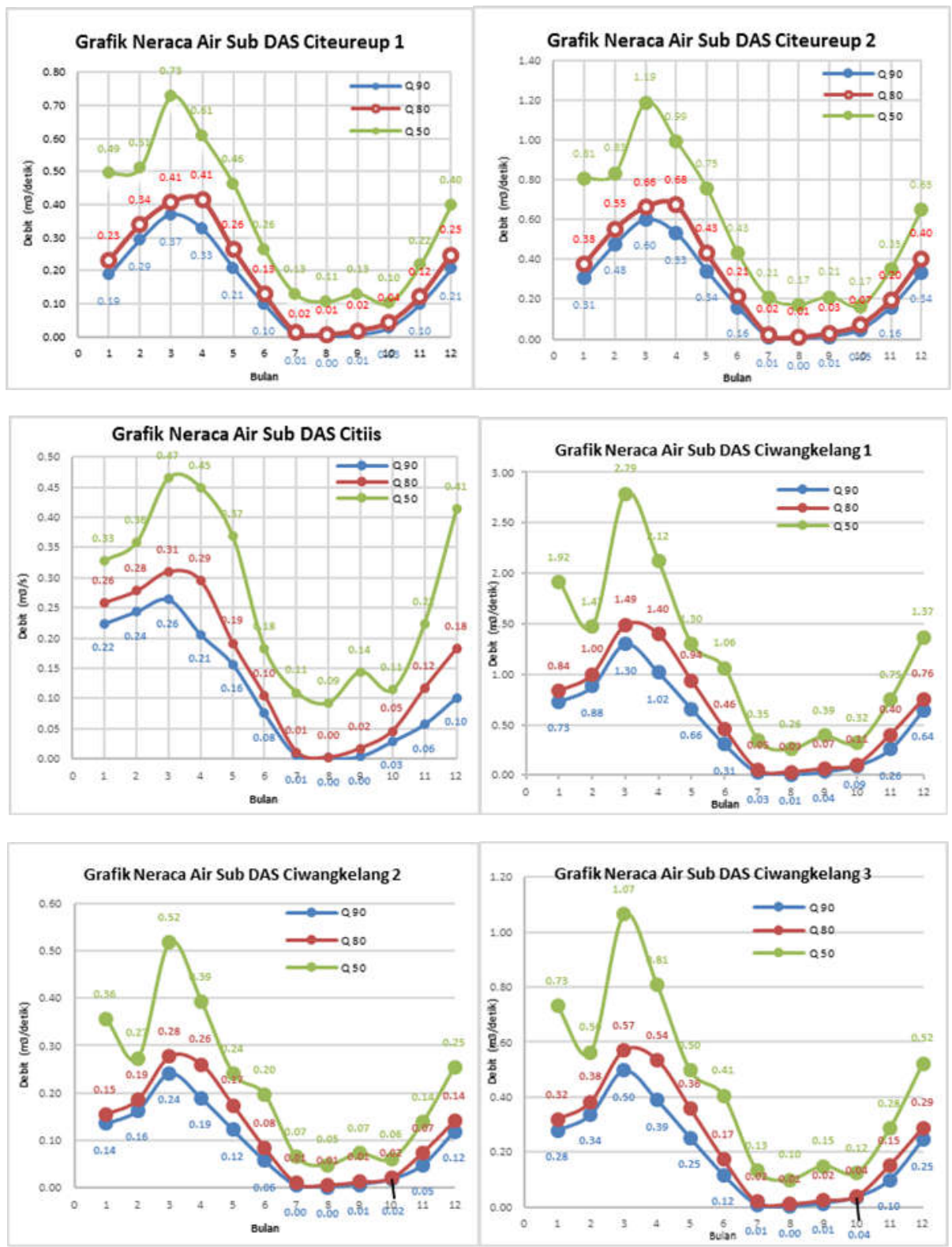

Gambar 7 Neraca Air pada 24 Sub DAS Ciliman

Berdasarkan Gambar 7 tentang grafik neraca air 24 sub-DAS Ciliman, diketahui bahwa debit puncak terjadi pada bulan Maret sedangkan debit minimum terjadi pada bulan Agustus. Berdasarkan perhitungan ketersediaan air, grafik yang dihasilkan dari masing-masing sub-DAS Ciliman memiliki pola yang sama, namun terkait debit yang tersedia pada masing-masing Sub DAS adalah pengaruh tutupan lahan pada tiap sub DAS (yang paling berpengaruh terhadap evapotranspirasi dan infiltrasi) dan luas pengaruh DAS berdasarkan analisis Polygon Thiessen terhadap rata-rata curah hujan bulanan. Debit andalan (Q80) dijadikan sebagai dasar dalam penentuan ketersediaan air dan merupakan potensi air yang tersedia di DAS Ciliman. Besarnya angka probabilitas yang akan diambil adalah $80 \%$ dengan pertimbangan bahwa keandalan $80 \%$ ini karena irigasi merupakan pengguna dan pemanfaat terbesar pada DAS Ciliman.

Sebagai contoh, Pada Gambar 8 terlihat bahwa Sub DAS Cibunar di hulu DAS Ciliman dengan luas $20,20 \mathrm{~km}^{2}$ terdiri dari tutupan lahan didominasi sawah irigasi seluas $13,64 \mathrm{~km}^{2}$, perkebunan seluas $3,74 \mathrm{~km}^{2}$ dan permukiman seluas $1,59 \mathrm{~km}^{2}$, diperoleh bahwa debit andalan pada sub DAS tersebut sebesar terjadi pada Bulan Januari yaitu $0,99 \mathrm{~m}^{3} /$ detik dan terendah pada Bulan Agustus yaitu $0,17 \mathrm{~m}^{3} /$ detik. Sub DAS Cikupaeun di tengah DAS Ciliman dengan luas $23,25 \mathrm{~km}^{2}$ terdiri dari tutupan lahan didominasi sawah irigasi seluas 11,05 $\mathrm{km}^{2}$, perkebunan seluas $10,01 \mathrm{~km}^{2}$ dan permukiman seluas $1,07 \mathrm{~km}^{2}$, diperoleh bahwa debit andalan pada sub DAS tersebut sebesar terjadi pada Bulan Januari yaitu $1,18 \mathrm{~m}^{3} /$ detik dan terendah pada Bulan Agustus yaitu $0,20 \mathrm{~m}^{3} /$ detik. Sub DAS Ciwangkelang 
1 di tengah DAS Ciliman dengan luas 18,52 $\mathrm{km}^{2}$ terdiri dari tutupan lahan didominasi perkebunan seluas 7,90 km², semak belukar seluas $6,52 \mathrm{~km}^{2}$ dan sawah irigasi seluas $1,40 \mathrm{~km}^{2}$, diperoleh bahwa debit andalan pada sub DAS tersebut sebesar terjadi pada Bulan Januari yaitu $0,91 \mathrm{~m}^{3} /$ detik dan terendah pada Bulan Agustus yaitu 0,17 $\mathrm{m}^{3} /$ detik. Sub DAS Cigoler di hilir DAS Ciliman dengan luas $17,62 \mathrm{~km}^{2}$ terdiri dari tutupan lahan didominasi semak belukar seluas $10,11 \mathrm{~km}^{2}$, perkebunan seluas $3,16 \mathrm{~km}^{2}$ dan sawah irigasi seluas 2,79 $\mathrm{km}^{2}$, diperoleh bahwa debit andalan pada sub DAS tersebut sebesar terjadi pada Bulan Januari yaitu $0,86 \mathrm{~m}^{3} /$ detik dan terendah pada Bulan Agustus yaitu 0,16 m³ $/$ detik.

\subsection{Analisis kebutuhan air}

Analisis kebutuhan air meliputi; kebutuhan air irigasi, kebutuhan air domestik, kebutuhan air untuk industri dan kebutuhan air untuk kawasan ekonomi khusus Tanjung Lesung. Kebutuhan air tersebut lebih rinci sebagai berikut:

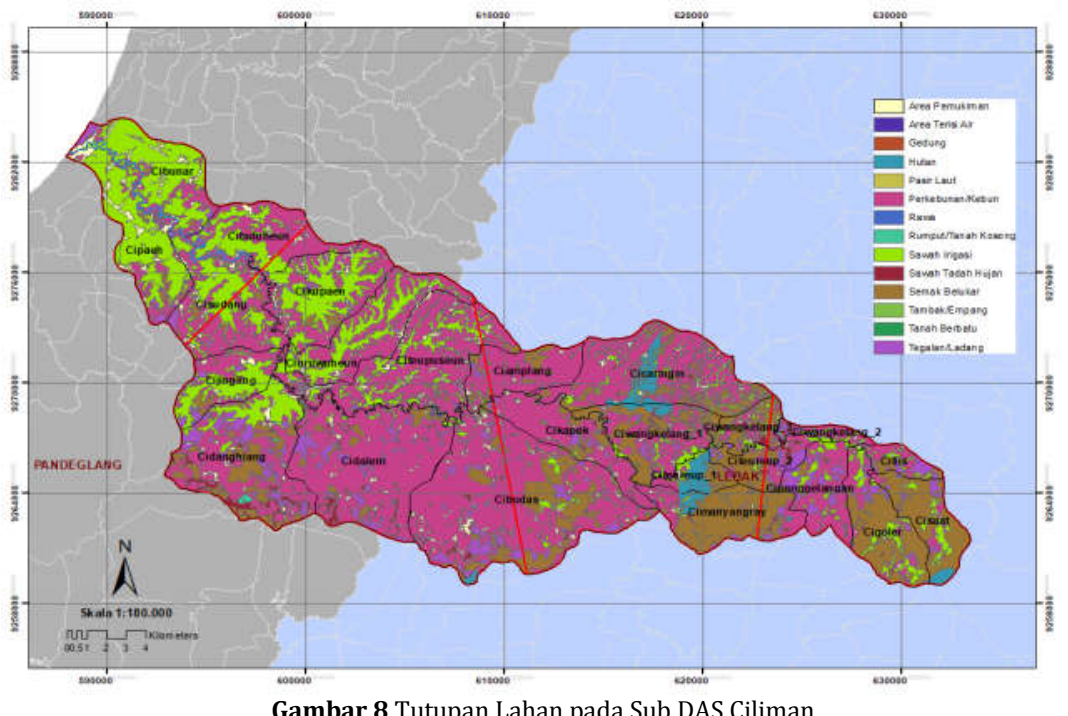

Tabel 2. Rekapitulasi Kebutuhan Air Irigasi DAS Ciliman

\begin{tabular}{|c|c|c|c|c|c|c|c|c|c|}
\hline \multirow{2}{*}{$\begin{array}{l}\text { Jenis Kebutuhan } \\
\text { Air }\end{array}$} & \multicolumn{6}{|c|}{ Alternatif } & \multicolumn{3}{|c|}{ Kebutuhan Air } \\
\hline & 1 & 2 & 3 & 4 & 5 & 6 & (lt/dt/Ha) & $\left(\mathrm{m}^{3} / \mathrm{dt} / \mathrm{Ha}\right)$ & $\left(\mathrm{m}^{3 / \operatorname{tahun} / \mathrm{Ha})}\right.$ \\
\hline NFR & 1.239 & 1.239 & 1.366 & 1.366 & 1.416 & 1.416 & 1.239 & 0,001 & 39.084 \\
\hline TDR & 1.548 & 1.548 & 1.708 & 1.708 & 1.770 & 1.770 & 1.548 & 0,002 & 48.855 \\
\hline SDR & 1.720 & 1.720 & 1.897 & 1.897 & 1.967 & 1.967 & 1.720 & 0,002 & 54.284 \\
\hline DR & 1.905 & 1.905 & 2.102 & 2.102 & 2.179 & 2.179 & 1.905 & 0,002 & 60.130 \\
\hline
\end{tabular}

Tabel 3. Proyeksi Kebutuhan Air Domestik Pada DAS Ciliman

\begin{tabular}{|c|c|c|c|c|c|c|c|}
\hline \multirow{3}{*}{ Nama Kecamatan } & \multirow{3}{*}{ Kabupaten } & \multirow{3}{*}{$\begin{array}{l}\text { Jumlah Penduduk } \\
2016\end{array}$} & \multicolumn{5}{|c|}{ Proyeksi Kebutuhan Air (m³ $/$ detik) } \\
\hline & & & 5 & 10 & 15 & 20 & 25 \\
\hline & & & 2021 & 2026 & 2031 & 2036 & 2041 \\
\hline Banjarsari & Lebak & 60.624 & 0,084 & 0,088 & 0,091 & 0,095 & 0,099 \\
\hline Cirinten & Lebak & 26.436 & 0,037 & 0,038 & 0,040 & 0,042 & 0,043 \\
\hline Gunung Kencana & Lebak & 34.625 & 0,048 & 0,050 & 0,052 & 0,054 & 0,057 \\
\hline Angsana & Pandeglang & 26.136 & 0,036 & 0,039 & 0,041 & 0,044 & 0,047 \\
\hline Munjul & Pandeglang & 22.903 & 0,032 & 0,034 & 0,036 & 0,039 & 0,041 \\
\hline Panimbang & Pandeglang & 51.142 & 0,071 & 0,076 & 0,081 & 0,086 & 0,092 \\
\hline Sindangresmi & Pandeglang & 21.969 & 0,031 & 0,033 & 0,035 & 0,037 & 0,040 \\
\hline Sobang & Pandeglang & 36.014 & 0,050 & 0,053 & 0,057 & 0,061 & 0,065 \\
\hline Sukaresmi & Pandeglang & 34.675 & 0,048 & 0,051 & 0,055 & 0,058 & 0,062 \\
\hline Jumlah & & & 0,48 & 0,50 & 0,53 & 0,56 & 0,60 \\
\hline
\end{tabular}


Tabel 4. Proyeksi Kebutuhan Air Industri di Area DAS Ciliman Proyeksi Jumlah Industri Sedang dan Jumlah Kebutuhan Air ( $\mathrm{m}^{3} /$ detik)

\begin{tabular}{|c|c|c|c|c|c|c|c|c|c|c|}
\hline \multirow{3}{*}{$\begin{array}{c}\text { Nama } \\
\text { Kecamatan }\end{array}$} & \multicolumn{10}{|c|}{ Proyeksi Jumlah Industri Sedang dan Jumlah Kebutuhan Air (m³/detik) } \\
\hline & \multicolumn{2}{|r|}{2021} & \multicolumn{2}{|r|}{2026} & \multicolumn{2}{|r|}{2031} & \multicolumn{2}{|r|}{2036} & \multicolumn{2}{|r|}{2041} \\
\hline & $\sum$ & Keb Air & $\sum$ & Keb Air & $\sum$ & Keb Air & $\sum$ & Keb Air & $\sum$ & Keb Air \\
\hline Munjul & 2 & 0,000020 & 2 & 0,000025 & 3 & 0,000032 & 4 & 0,000041 & 5 & 0,000052 \\
\hline
\end{tabular}

Tabel 5. Proyeksi Kebutuhan Air Kawasan Ekonomi Khusus Tanjung Lesung

\begin{tabular}{lccccc}
\hline & \multicolumn{5}{c}{ Kebutuhan Air (liter/detik) } \\
\cline { 2 - 6 } \multicolumn{1}{c}{ Uraian } & 2018 & 2023 & 2028 & 2033 & 2038 \\
\hline Desa Citeureup & 2,94 & 3,24 & 3,58 & 3,95 & 4,36 \\
Desa Gombong & 2,50 & 2,77 & 3,05 & 3,37 & 3,72 \\
Desa Mekarsari & 3,11 & 3,44 & 3,79 & 4,19 & 4,62 \\
Desa Panimbang Jaya & 3,77 & 4,16 & 4,60 & 5,07 & 5,60 \\
Bandara & 12,10 & 12,10 & 12,10 & 12,10 & 12,10 \\
Kawasan Tanjung Lesung & 400,00 & 400,00 & 400,00 & 400,00 & 400,00 \\
\hline Total & 424,42 & 425,71 & 427,12 & 428,68 & 430,40 \\
\hline
\end{tabular}

Berdasarkan perhitungan hujan wilayah dengan metode Thiessen Polygon diperoleh distribusi hujan rata-rata bulanan dari data 18 tahun (1998-2016), yang kemudian dipergunakan sebagai input analisis ketersediaan air dengan metode Pennman Modifikasi. Analisis imbangan ketersediaan dan kebutuhan air (neraca air) dilakukan terhadap hasil pengolahan data melalui dua tahap, yaitu tahap analisis neraca air pada kondisi eksisting yang dilakukan untuk kepentingan yang bersifat sementara, dan analisis neraca air di masa mendatang yang bersifat jangka panjang, yaitu pada kondisi waktu-waktu yang diproyeksikan selama 20 tahun ke depan.Total kebutuhan air untuk area DAS Ciliman adalah mencapai $38,86 \mathrm{~m}^{3} /$ detik, terdiri atas; kebutuhan air untuk irigasi merupakan kebutuhan air tertinggi yakni mencapai 37,96 $\mathrm{m}^{3} /$ detik dengan total luas lahan irigasi ciliman mencapai 5.423 hektar. Kebutuhan air untuk domestik adalah $0,48 \mathrm{~m}^{3} /$ detik dengan total penduduk yang terlayani 314.524 jiwa. Kebutuhan Industri di daerah hilir Daerah Aliran Sungai Ciliman adalah industri sedang dengan besar kebutuhan air industri 0,000041 $\mathrm{m}^{3} /$ det. Sedangkan kebutuhan air untuk Kawasan Ekonomi Khusus Tanjung Lesung adalah 0,42442 $\mathrm{m}^{3} /$ detik. Jenis dan jumlah kebutuhan air keseluruhan di DAS Ciliman berdasarkan hasil perhitungan bulanan dapat dilihat pada Tabel 6. Berdasarkan tabel tersebut, total kebutuhan air terbesar adalah pada Bulan Maret yaitu sebesar $18,989 \mathrm{~m}^{3} /$ detik dan terendah yaitu di Bulan Oktober sebesar 0,184 $\mathrm{m}^{3} /$ detik. Sedangkan jenis dan jumlah kebutuhan air keseluruhan di bendung Ciliman berdasarkan hasil perhitungan bulanan dapat dilihat pada Tabel 7 .

\begin{tabular}{|c|c|c|c|c|c|c|c|c|c|c|c|c|}
\hline & Jan & Feb & Mar & Apr & May & Jun & Jul & Aug & Sep & Oct & Nov & Dec \\
\hline AB Angsana & 0,041 & 0,041 & 0,041 & 0,041 & 0,041 & 0,041 & 0,041 & 0,041 & 0,041 & 0,041 & 0,041 & 0,041 \\
\hline AB Banjarsari & 0,092 & 0,092 & 0,092 & 0,092 & 0,092 & 0,092 & 0,092 & 0,092 & 0,092 & 0,092 & 0,092 & 0,092 \\
\hline $\mathrm{AB}$ Cirinten & 0,040 & 0,040 & 0,040 & 0,040 & 0,040 & 0,040 & 0,040 & 0,040 & 0,040 & 0,040 & 0,040 & 0,040 \\
\hline $\begin{array}{l}\text { AB Gunung } \\
\text { Kencana }\end{array}$ & 0,052 & 0,052 & 0,052 & 0,052 & 0,052 & 0,052 & 0,052 & 0,052 & 0,052 & 0,052 & 0,052 & 0,052 \\
\hline AB Munjul & 0,036 & 0,036 & 0,036 & 0,036 & 0,036 & 0,036 & 0,036 & 0,036 & 0,036 & 0,036 & 0,036 & 0,036 \\
\hline $\begin{array}{l}\mathrm{AB} \\
\text { Sindangresmi }\end{array}$ & 0,035 & 0,035 & 0,035 & 0,035 & 0,035 & 0,035 & 0,035 & 0,035 & 0,035 & 0,035 & 0,035 & 0,035 \\
\hline AB Sobang & 0,057 & 0,057 & 0,057 & 0,057 & 0,057 & 0,057 & 0,057 & 0,057 & 0,057 & 0,057 & 0,057 & 0,057 \\
\hline AB Sukaresmi & 0,055 & 0,055 & 0,055 & 0,055 & 0,055 & 0,055 & 0,055 & 0,055 & 0,055 & 0,055 & 0,055 & 0,055 \\
\hline AB Panimbang & 0,081 & 0,081 & 0,081 & 0,081 & 0,081 & 0,081 & 0,081 & 0,081 & 0,081 & 0,081 & 0,081 & 0,081 \\
\hline Bandara & 0,012 & 0,012 & 0,012 & 0,012 & 0,012 & 0,012 & 0,012 & 0,012 & 0,012 & 0,012 & 0,012 & 0,012 \\
\hline Cibodas & 0,051 & 0,193 & 0,306 & 0,240 & 0,228 & 0,075 & 0,003 & 0,158 & 0,079 & 0,000 & 0,236 & 0,073 \\
\hline Cibulakan & 0,040 & 0,155 & 0,245 & 0,192 & 0,183 & 0,060 & 0,003 & 0,126 & 0,063 & 0,000 & 0,189 & 0,058 \\
\hline Cilimus & 0,040 & 0,155 & 0,245 & 0,192 & 0,183 & 0,060 & 0,003 & 0,126 & 0,063 & 0,000 & 0,189 & 0,058 \\
\hline Ind. Munjul & $2.10^{-5}$ & $2.10^{-5}$ & $2.10^{-5}$ & $2.10^{-5}$ & $2.10^{-5}$ & $2.10^{-5}$ & $2.10^{-5}$ & $2.10^{-5}$ & $2.10^{-5}$ & $2.10^{-5}$ & $2.10^{-5}$ & $2.10^{-5}$ \\
\hline Ciliman & 2,739 & 10,475 & 16,601 & 13,030 & 12,383 & 4,089 & 0,183 & 8,566 & 4,259 & 0,000 & 12,796 & 3,957 \\
\hline Citiis & 0,035 & 0,135 & 0,214 & 0,168 & 0,160 & 0,053 & 0,002 & 0,111 & 0,055 & 0,000 & 0,165 & 0,051 \\
\hline $\begin{array}{l}\text { Pompa Kramat } \\
\text { Jaya }\end{array}$ & 0,055 & 0,209 & 0,331 & 0,259 & 0,247 & 0,081 & 0,004 & 0,171 & 0,085 & 0,000 & 0,255 & 0,079 \\
\hline Cipanggelangan & 0,044 & 0,168 & 0,266 & 0,209 & 0,199 & 0,066 & 0,003 & 0,137 & 0,068 & 0,000 & 0,205 & 0,063 \\
\hline Cimanyangray & 0,098 & 0,377 & 0,597 & 0,469 & 0,445 & 0,147 & 0,007 & 0,308 & 0,153 & 0,000 & 0,460 & 0,142 \\
\hline KEK Tg Lesung & 0,400 & 0,400 & 0,400 & 0,400 & 0,400 & 0,400 & 0,400 & 0,400 & 0,400 & 0,400 & 0,400 & 0,400 \\
\hline $\begin{array}{l}\text { Total Keb. Air } \\
\text { DAS Ciliman } \\
\left(\mathrm{m}^{3} / \mathrm{dt}\right)\end{array}$ & 4,005 & 12,768 & 19,707 & 15,661 & 14,929 & 5,533 & 1,108 & 10,605 & 5,726 & 0,902 & 15,397 & 5,384 \\
\hline
\end{tabular}

Sumber : Hasil Analisis Tahun 2018 
Tabel 7. Kebutuhan Air di Bendung Ciliman

\begin{tabular}{|c|c|c|c|c|c|c|c|c|c|c|c|c|}
\hline & Jan & Feb & Mar & Apr & May & Jun & Jul & Aug & Sep & Oct & Nov & Dec \\
\hline AB. Banjarsari & 0,092 & 0,092 & 0,092 & 0,092 & 0,092 & 0,092 & 0,092 & 0,092 & 0,092 & 0,092 & 0,092 & 0,092 \\
\hline AB. Cirinten & 0,040 & 0,040 & 0,040 & 0,040 & 0,040 & 0,040 & 0,040 & 0,040 & 0,040 & 0,040 & 0,040 & 0,040 \\
\hline $\begin{array}{l}\text { AB. Gunung } \\
\text { Kencana }\end{array}$ & 0,052 & 0,052 & 0,052 & 0,052 & 0,052 & 0,052 & 0,052 & 0,052 & 0,052 & 0,052 & 0,052 & 0,052 \\
\hline Cibodas & 0,051 & 0,193 & 0,306 & 0,240 & 0,228 & 0,075 & 0,003 & 0,158 & 0,079 & 0,000 & 0,236 & 0,073 \\
\hline Cibulakan & 0,040 & 0,155 & 0,245 & 0,192 & 0,183 & 0,060 & 0,003 & 0,126 & 0,063 & 0,000 & 0,189 & 0,058 \\
\hline Cilimus & 0,040 & 0,155 & 0,245 & 0,192 & 0,183 & 0,060 & 0,003 & 0,126 & 0,063 & 0,000 & 0,189 & 0,058 \\
\hline Ciliman & 2,739 & 10,475 & 16,601 & 13,030 & 12,383 & 4,089 & 0,183 & 8,566 & 4,259 & 0,000 & 12,796 & 3,957 \\
\hline Citiis & 0,035 & 0,135 & 0,214 & 0,168 & 0,160 & 0,053 & 0,002 & 0,111 & 0,055 & 0,000 & 0,165 & 0,051 \\
\hline $\begin{array}{l}\text { Pompa Kramat } \\
\text { Jaya }\end{array}$ & 0,055 & 0,209 & 0,331 & 0,259 & 0,247 & 0,081 & 0,004 & 0,171 & 0,085 & 0,000 & 0,255 & 0,079 \\
\hline Cipanggelangan & 0,044 & 0,168 & 0,266 & 0,209 & 0,199 & 0,066 & 0,003 & 0,137 & 0,068 & 0,000 & 0,205 & 0,063 \\
\hline Cimanyangray & 0,098 & 0,377 & 0,597 & 0,469 & 0,445 & 0,147 & 0,007 & 0,308 & 0,153 & 0,000 & 0,460 & 0,142 \\
\hline $\begin{array}{l}\text { Total Kebutuhan } \\
\text { Air di Bd Ciliman } \\
\left(\mathrm{m}^{3} / \mathrm{dt}\right)\end{array}$ & 3,287 & 12,050 & 18,989 & 14,943 & 14,211 & 4,815 & 0,391 & 9,887 & 5,009 & 0,184 & 14,679 & 4,666 \\
\hline
\end{tabular}

\subsection{Analisis Keseimbangan Air (Water Balanced)}

Analisis keseimbangan air adalah selisih antara jumlah ketersediaan air dengan kebutuhan air pada Daerah Aliran Sungai Ciliman. Hasil selisih antara jumlah ketersediaan air dengan kebutuhan air dianalisis menurut waktu yang dimanfaatkan baik dalam tengah bulanan maupun bulanan berdasarkan titik pengambilan atau alokasi air yang telah ditentukan. Berdasarkan hasil analisa ketersediaan air di Bendung Ciliman sebesar 103,94 $\mathrm{m}^{3} /$ detik, sedangkan kebutuhan airnya sebesar 103,11 $\mathrm{m}^{3} /$ detik. Hal ini berarti terdapat surplus sebesar 0,83 $\mathrm{m}^{3} /$ detik. Neraca air bendung Ciliman Tahun 1998-2016 ditampilkan pada Tabel 8. Secara diagramatis, hasil analisis neraca air bendung ciliman dapat dilihat pada Gambar 9.

Tabel 8. Neraca Air Bendung Ciliman Tahun 1998-2016

\begin{tabular}{ccccc}
\hline Bulan & $\begin{array}{c}\text { Ketersediaan } \\
\left(\mathrm{m}^{3} / \mathrm{dt}\right)\end{array}$ & $\begin{array}{c}\text { Kebutuhan } \\
\left(\mathrm{m}^{3} / \mathrm{dt}\right)\end{array}$ & $\begin{array}{c}\text { Neraca Air } \\
\left(\mathrm{m}^{3} / \mathrm{dt}\right)\end{array}$ & Kondisi \\
\hline Jun & 5.54 & 4.82 & 0.72 & Surplus \\
Jul & 0.86 & 0.39 & 0.47 & Surplus \\
Aug & 0.45 & 9.89 & -9.44 & Defisit \\
Sep & 0.74 & 5.01 & -4.27 & Defisit \\
Oct & 2.02 & 0.18 & 1.84 & Surplus \\
Nov & 7.37 & 14.68 & -7.30 & Defisit \\
Dec & 12.92 & 4.67 & 8.25 & Surplus \\
Jan & 11.63 & 3.29 & 8.34 & Surplus \\
Feb & 15.48 & 12.05 & 3.43 & Surplus \\
Mar & 18.18 & 18.99 & -0.81 & Defisit \\
Apr & 17.60 & 14.94 & 2.65 & Surplus \\
May & 11.16 & 14.21 & -3.05 & Defisit \\
\hline Jumlah & 103.94 & 103.11 & 0.83 & Surplus \\
\hline
\end{tabular}

Sumber : Hasil Analisis Tahun 2018

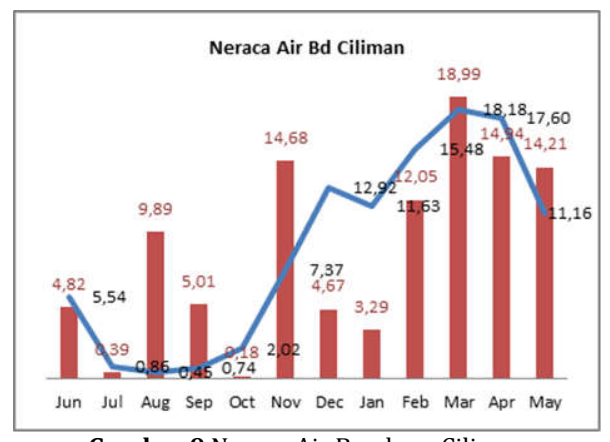

Gambar 9 Neraca Air Bendung Ciliman
Hasil perhitungan neraca air pada Daerah Aliran Sungai Ciliman Tahun 1998-2016 dapat dilihat pada Tabel 9 dan Gambar 10.

Tabel 10. Neraca Air DAS Ciliman Tahun 1998-2016 Bulan Ketersediaan Kebutuhan Neraca Air $\left(\mathrm{m}^{3} / \mathrm{dt}\right)$ Kondisi $\left(\mathrm{m}^{3} / \mathrm{dt}\right) \quad\left(\mathrm{m}^{3} / \mathrm{dt}\right)$

$\begin{array}{ccccc}\text { Jun } & 10.52 & 5.53 & 4.99 & \text { Surplus } \\ \text { Jul } & 1.45 & 1.11 & 0.34 & \text { Surplus } \\ \text { Aug } & 1.29 & 10.60 & -9.32 & \text { Defisit } \\ \text { Sep } & 0.97 & 5.73 & -4.76 & \text { Defisit } \\ \text { Oct } & 2.56 & 0.90 & 1.66 & \text { Surplus } \\ \text { Nov } & 17.04 & 15.40 & 1.65 & \text { Surplus } \\ \text { Dec } & 27.53 & 5.38 & 22.14 & \text { Surplus } \\ \text { Jan } & 23.62 & 4.00 & 19.62 & \text { Surplus } \\ \text { Feb } & 30.25 & 12.77 & 17.48 & \text { Surplus } \\ \text { Mar } & 34.52 & 19.71 & 14.82 & \text { Surplus } \\ \text { Apr } & 40.33 & 15.66 & 24.67 & \text { Surplus } \\ \text { May } & 20.65 & 14.93 & 5.72 & \text { Surplus } \\ \text { Jumlah } & 210.73 & 111.72 & 99.00 & \text { Surplus }\end{array}$

Sumber : Hasil Analisis Tahun 2018

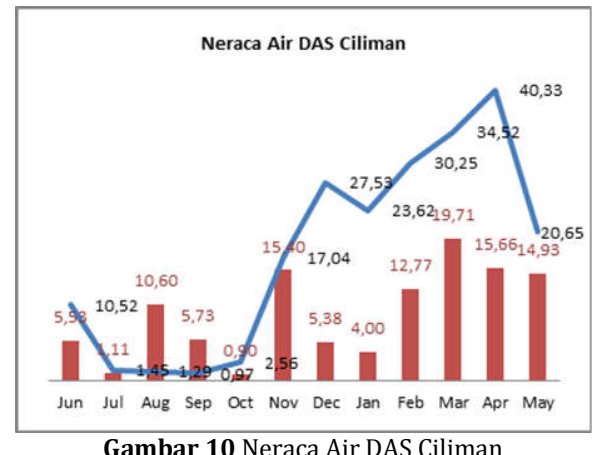

Hasil analisis di atas menunjukan bahwa secara umum jumlah ketersediaan air di Daerah Aliran Sungai Ciliman cukup dalam memenuhi kebutuhan air dalam kurun waktu satu tahun tetapi masih terdapat defisit air selama tiga bulan pada Bulan Juli, Agustus dan September. 


\section{Kesimpulan}

Secara keseluruhan, air yang tersedia pada DAS Ciliman tergolong mencukupi, namun jika dilihat dari grafik neraca air bulanan, masih terjadi defisit air selama 3 (tiga) bulan yaitu pada Bulan JuliSeptember. Dari beberapa uraian diatas, secara keseluruhan dapat disimpulkan bahwa :

1. Ketersediaan air di bendung Ciliman dari data debit sintetis menggunakan metode mock tahun 1998-2016

2. Kebutuhan air yang digunakan dari hulu sampai Bendung Ciliman yakni Irigasi Citiis $(1,15$ $\mathrm{m}^{3} /$ detik), Irigasi Cipanggelangan $\left(1,43 \mathrm{~m}^{3} /\right.$ detik), Air Baku Cirinten $\left(0,48 \mathrm{~m}^{3} /\right.$ detik $)$, Irigasi Cibulakan $\left(1,31 \mathrm{~m}^{3} /\right.$ detik$)$, Irigasi Cilimus $(1,31$ $\mathrm{m}^{3} /$ detik), Irigasi Pompa Kramat Jaya $(1,77$ $\mathrm{m}^{3} /$ detik), Irigasi Cimanyangray $\left(3,2 \mathrm{~m}^{3} /\right.$ detik), Air Baku Gunung Kencana $\left(0,63 \mathrm{~m}^{3} /\right.$ detik), Air Baku Banjarsari $\left(1,1 \mathrm{~m}^{3} /\right.$ detik), Irigasi Cibodas $\left(1,64 \mathrm{~m}^{3} /\right.$ detik $)$, dan Irigasi Ciliman $(89,08$ $\mathrm{m}^{3} /$ detik).

3. Hasil analisa ketersediaan air di Bendung Ciliman sebesar $103,94 \mathrm{~m}^{3} /$ detik, sedangkan kebutuhan airnya sebesar $103,11 \mathrm{~m}^{3} /$ detik.

4. Maka dari butir 3 di atas didapat neraca air total di Bendung Ciliman masih terdapat surplus sebesar $0,83 \mathrm{~m}^{3} /$ detik.

5. Menurut analisa neraca air bulanan terjadi defisit di Bulan Agustus, September, November, Maret, dan Mei.

6. Jika di analisa neraca air seluruh DAS Ciliman masih terdapat surplus sebesar $99 \mathrm{~m}^{3} /$ detik.

\section{Saran}

Mengingat terus meningkatnya jumlah penduduk, maka di DAS Ciliman perlu direncanakan pengembangan infrastruktur bangunan air berupa waduk atau bendungan untuk menambah ketersediaan air serta alokasi air berdasarkan prioritas kebutuhan.

\section{DAFTAR PUSTAKA}

Arsyad, S., 2006. Konservasi Tanah dan Air. Edisi kedua. IPB Press. Bogor.

Asdak, C., 2007. Hidrologi dan Pengelolaan Daerah Aliran Sungai, Cetakan keempat, Yogyakarta, Gadjah Mada University Press.

Azmanajaya, E., 2012. Model Penyediaan Air Bersih Berkelanjutan di Pulau Kecil Studi Kasus : Pulau Tarakan, Kalimantan Timur. Disertasi. Institut Pertanian Bogor.
Badan Lingkungan Hidup Daerah Provinsi Banten. 2015. Profil Ekosistem DAS Ciliman.

Direktorat Jendral Sumber Daya Air. 2011. Standar Perencanaan Irigasi. Jakarta: Direktorat Jendral Sumber Daya Air.

Dinas Sumber Daya Air dan Permukiman Provinsi Banten. 2013. Pola Pengelolaan Sumber Daya Air Wilayah Sungai Ciliman-Cibungur.

Dinas Sumber Daya Air dan Permukiman. 2014. DED Penyediaan Air Baku Kawasan Tanjung Lesung.

Dinas Sumber Daya Air dan Permukiman Provinsi Banten. 2015. Studi Komprehensif Pengendalian Daya Rusak Air Pada DAS Ciliman.

Dinas Sumber Daya Air dan Permukiman. 2016. Penyusunan Perencanaan dan Evaluasi Alokasi Air Pada DAS Ciliman.

Direktorat Jendral Cipta Karya Kementerian PUPR. 2016. Perencanaan Pengembangan SPAM Mendukung Kawasan Strategis Pariwisata Nasional Wilayah Barat.

Dinas Pekerjaan Umum dan Penataan Ruang. 2017. Pra FS Pembangunan Multipurpose DAM pada DAS Ciliman.

Dinas Pekerjaan Umum dan Penataan Ruang. 2018. FS Pembangunan Multipurpose DAM pada DAS Ciliman

Hasan, M., 2011. Model Kebijakan Pengelolaan SumberDaya Air Pada Daerah Aliran Sungai (DAS) Citarum Yang Berkelanjutan. Disertasi. Institut Pertanian Bogor.

Hatmoko, W., Radhika., Amirwandi, S., Fauzi, M., Firmansyah, R., Solihah, R., Fathoni, A., 2012. Neraca Ketersediaan dan Kebutuhan Air pada Wilayah Sungai di Indonesia. Bandung : Pusat Penelitian dan Pengembangan Sumber Daya Air

Hatmoko, W., Radhika., Raharja, B., Tollenaar, D., Vernimmen, R., 2015. Monitoring and prediction of hydrological drought using a drought early warning system in Pemali Comal river basin, Indonesia. Procedia Environmental Sciences 24 (2015) 56-64. Elsevier.B.V

Marpaung, R., 2013, Model Pengelolaan Air Baku Air Minum Berbasis Daerah Aliran Sungai Studi Kasus DAS Babon Semarang. Disertasi. Institut Pertanian Bogor.

Mubarok, D.A., 2018, Perencanaan Bendungan Ciliman di Kabupaten Lebak Banten, Tugas Akhir, Institut Teknologi Bandung.

Sari dkk. 2011. Analisa Ketersediaan dan Kebutuhan Air pada DAS Sampean. Jurnal Pengairan Universitas Brawijaya Vol 2 No 1.

Sitompul dan Efrida. 2018. Evaluasi Ketersediaan Air DAS Deli terhadap Kebutuhan Air. Jurnal Rekayasa Sipil Universitas Andalas Vol 14 No 2, Oktober 2018. Hal 121-129. ISSN 2477-3484

Sukmanda dan Terunajaya. 2016. Analisa Ketersediaan dan Kebutuhan Air pada DAS Percut untuk Memenuhi Kebutuhan Air Bersih di Kabupaten Deli Serdang. Jurnal Teknik Sipil Universitas Sumatera Utara. 